\title{
The Effectiveness of Bandotan (Ageratum conyzoides L.) Leaf Extract on Mortality of Boophilus microplus In Vitro
}

\author{
${ }^{1)}$ Dwi Retno Widyawati, ${ }^{2)}$ Iwan Sahrial Hamid D, ${ }^{2)}$ Moh. Sukmanadi, ${ }^{2)}$ Sri Agus Sudjarwo, \\ 3)Muhammad Hambal \\ ${ }^{1)}$ Student, Faculty of Veterinary Medicine, Universitas Airlangga, dwi.retno.widyawati- \\ 2017@fkh.unair.ac.id \\ ${ }^{2)}$ Division of Veterinary Basic, Faculty of Veterinary Medicine, Universitas Airlangga \\ 3) Department of Veterinary Parasitology, Faculty of Veterinary Medicine, Universitas Syiah Kuala
}

Corresponding author: iwan-s-h@fkh.unair.ac.id

\begin{abstract}
The purpose of this research is to find the effectiveness of bandotan's (Ageratum conyzoides L.) leaf extract on mortality of Boophilus microplus in vitro and also to get of lethal concentration and lethal time. This research used 125 Boophilus microplus. This research used five treatments, namely neguvon suspensionon $(\mathrm{K}+)$, ethanol $1 \%(\mathrm{~K}-)$, $1 \%$ concentration $\left(\mathrm{P}_{1}\right), 2 \%$ concentration $\left(\mathrm{P}_{2}\right)$ and $3 \%$ concentration $\left(\mathrm{P}_{3}\right)$. The observation of mortality was done every six hours. Boophilus microplus dies when there is no movement. The data were analyzed using one-way ANOVA and followed by Duncan's Multiple Distance Test. The result is said to be significant if $\mathrm{p}<0.05$. Probit analysis of $\mathrm{LC}_{50}$ is $1.63 \%$ at the first hour, $0.85 \%$ at the second hour, $0.54 \%$ at the third hour, $0.34 \%$ at the fourth hour, $0.04 \%$ at the fifth hour and $0.04 \%$ at the sixth hour, $\mathrm{LC}_{90}$ reached by using $5.6 \%, 2.9 \%, 1.8 \%$, $1.2 \%, 0.16$ and $0.16 \%$ concentration in $1,2,3,4,5$ and 6 hours, respectively. The $\mathrm{LT}_{50}$ of ethanol $1 \%(\mathrm{~K}-)$ was at 10.142 hours, neguvon suspension on $(\mathrm{K}+)$ was at 0.747 hours, $1 \%$ concentration $\left(\mathrm{P}_{1}\right)$ was at 2.184 hours, $2 \%$ concentration $\left(\mathrm{P}_{2}\right)$ was at 1.579 hours, 3\% concentration $\left(\mathrm{P}_{3}\right)$ was at 0.923 hours and $\mathrm{LT}_{90}$ was at 23.734, 1.749, 5.110, 3.695 and 2.159 hours. The conclusion of this study was bandotan's (Ageratum conyzoides L.) leaf extract was effective as an acaricide based on the mortality of Boophilus microplus.
\end{abstract}

Keywords: Ageratum conyzoides, Boophilus microplus, leaf extract, neguvon, probit analysis, leaf extract

\section{Introduction}

Tick is one of the important ectoparasites of the subphylum Chelicerata and often infests cattle by sucking blood on the body surface of livestock. Boophilus microplus is a tick that has thick skin and is important in cattle farming because it causes great losses. Ticks can act as hosts between diseases caused by protozoa, bacteria, viruses, spirochaetes, rickettsiae, chlamydia and other disease agents (Hendrix, 2012). Wounds from the bite of a large number of ticks can attract Chrysomia flies (green flies) to lay eggs on the wound and then cause myiasis. These conditions can cause the livestock body to become weak, decreased appetite, fever accompanied by decreased milk production and body weight. Another disadvantage of tick infestation is that the selling price of cowhide is cheap or it is rejected, which is detrimental to farmers (Sukarsih et al., 1999; Gunandini, 2006).

The losses caused by B. microplus infestation are quite large in livestock. This loss can be minimized in various ways. The way farmers deal with $B$. microplus infestations is by taking and killing ticks one by one, scraping using a knife, bathing the livestock using soap and using synthetic acaricides from the officers (Manurug, 2002). Indiscriminate and repeated use of synthetic acaricides can cause various problems. These problems are related to environmental pollution, development of resistance in target species and the subsequent increase in costs (Jonsson and Piper, 2007). Many problems arise due to the use of synthetic acaricides. It is necessary to look for medicinal materials that are able to kill ticks without any resistance, prices are relatively cheap and easy to obtain, so that they are affordable by farmers 
in rural areas, safe for the environment and human health.

Bandotan plant (Ageratum conyzoides L.) is a nuisance weed that lives in the wild and is found in many areas, although people often think of it as a nuisance plant. Kardinan (in Shinta, 2010) explains the potential of bandotan as a vegetable pesticide/insecticide because it contains compounds including saponins, flavonoids, polyphenols, alkaloids, edultin, friedelin, and prekosenkumarine, 5\% eugenol, $\mathrm{HCN}$, and essential oils. Bandotan plants as insecticides and nematicides (Octavia et al., 2008; Samsudin, 2008). Rosida (2005) proved that bandotan leaf extract functions as a larvicide that can eradicate Aedes aegypti mosquito larvae. The content in bandotan leaves is the basis of reference that bandotan leaves can be used as a vegetable acaricide against $B$. microplus. Research on bandotan leaves as an acaricide is still very rare or not even done. Based on the above, the researchers want to test the effectiveness of acaricide in bandotan leaf extract on mortality of $B$. microplus in vitro by using the spraying method.

\section{Materials and Methods}

This study used a post test control only group design. Each treatment used five repetitions and each replication used $5 B$. microplus. The treatments consisted of $1 \%$ ethanol solvent $(\mathrm{K}-)$, neguvon suspension $(\mathrm{K}+)$, bandotan leaf extract at a concentration of $1 \%$ $(\mathrm{Pl}), 2 \%\left(\mathrm{P}_{2}\right)$, and $3 \%\left(\mathrm{P}_{3}\right)$.

Observation of tick death time was carried out every 1 hour for 6 hours. Observations were made by calculating the percentage of dead ticks. Dead ticks are characterized by a rigid body condition with irregular foot positions, not moving, and not responding to stimuli when touched (Wahyu, 2017).

The research sample was obtained from adult ticks which have the same relative size from Ongole Peranakan cattle in Tahunan Village, Sale Sub-District. The ticks were taken carefully so that no parts were cut off, then put into a sample bottle and immediately brought to the Laboratory of the Fisheries and Livestock Service Office of Blora District for observation and testing.

Observations and records were made of the number of dead ticks. The data obtained were analyzed using a one-way analysis of variance parametric test (One Way ANOVA), which was followed by Duncan's follow-up test. Probit analysis was used to determine the $\mathrm{LC}_{50}$, LC9o, LT5o and LT9o of bandotan leaf extract at each hour of observation.

\section{Results and Discussion}

The identification of $B$. microplus ticks in this study was carried out macroscopically. The results of macroscopic identification showed that the B. microplus tick has a body covered with thick skin (integument), so it is included in the hard tick category. The dorsal part of this tick has a scutum or shield that covers the entire dorsal body of the male tick, while in the female the scutum only covers the anterior third of the body, therefore the female tick's body can grow larger than the male after sucking blood (Fig. 1).

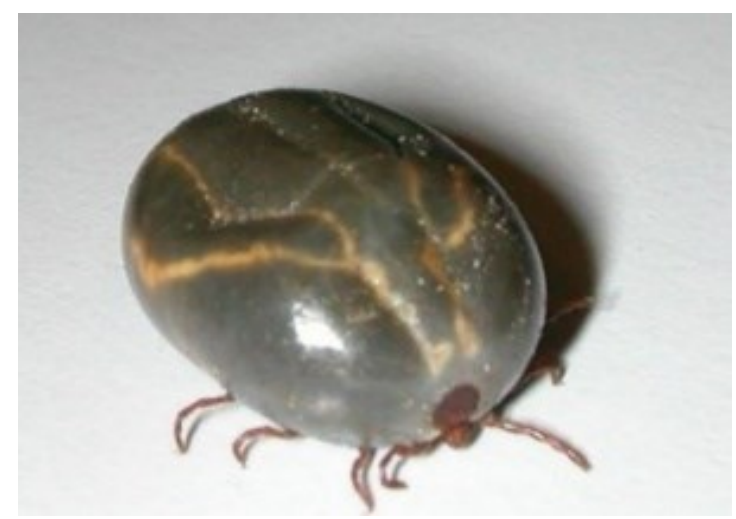

Figure 1. Boophilus microplus after suck blood of host.

The results showed that $B$. microplus that had been given bandotan leaf extract by spraying had differences with the controls who were not given any treatment. The treated ticks changed color to green due to exposure to bandotan leaf extract. Another visible change is the tick's body becomes stiff with an irregular foot position, not moving. Based on the results of statistical analysis using one- way ANOVA, it was found that there was a significant difference between treatment groups in the average number of deaths of $B$. microplus at each hour of observation $(\mathrm{p}<0.05)$. In Duncan's multiple-distance test, the mean and standard deviation of the mortality of $B$. microplus were obtained. The mean and standard deviation of mortality of $B$. microplus due to the administration of bandotan leaf extract at every hour of observation can be seen in Table 1 . 
Table 1. Mean and Standard Deviation of Mortality of B. microplus given Bandotan Leaf Extract.

\begin{tabular}{|c|c|c|c|c|c|c|}
\hline \multirow{2}{*}{ Treatment } & \multicolumn{6}{|c|}{ Observation Time } \\
\hline & $1^{\text {st }}$ hour & $2^{\text {nd }}$ hour & $3^{\text {rd }}$ hour & $4^{\text {th }}$ hour & $5^{\text {th }}$ hour & $6^{\text {th }}$ hour \\
\hline $\mathrm{K}(+)$ & $\begin{array}{c}64.00^{\mathrm{d}} \pm \\
16.733\end{array}$ & $\begin{array}{c}92.00^{\mathrm{C}} \pm \\
10.954\end{array}$ & $\begin{array}{c}100.00^{\mathrm{C}} \pm \\
0.000\end{array}$ & $\begin{array}{c}100.00^{\mathrm{C}} \pm \\
0.000\end{array}$ & $\begin{array}{c}100.00^{\mathrm{b}} \pm \\
0.000\end{array}$ & $\begin{array}{c}100.00^{\mathrm{b}} \pm \\
0.000\end{array}$ \\
\hline $\mathrm{K}(-)$ & $\begin{array}{c}0.00^{\mathrm{a}} \pm \\
0.000\end{array}$ & $\begin{array}{c}4.00^{\mathrm{a}} \pm \\
8.944\end{array}$ & $\begin{array}{c}16.00^{\mathrm{a}} \pm \\
8.944\end{array}$ & $\begin{array}{c}24.00^{\mathrm{a}} \pm \\
16.733\end{array}$ & $\begin{array}{c}36.00^{\mathrm{a}} \pm \\
16.733\end{array}$ & $\begin{array}{c}44.00^{\mathrm{a}} \pm \\
21.909\end{array}$ \\
\hline $\mathrm{P}_{1}$ & $\begin{array}{c}16.00^{b} \pm \\
8.944\end{array}$ & $\begin{array}{c}44.00^{b} \pm \\
8.944\end{array}$ & $\begin{array}{c}64.00^{\mathrm{b}} \pm \\
16.733\end{array}$ & $\begin{array}{c}72.00^{\mathrm{b}} \pm \\
17.889\end{array}$ & $\begin{array}{c}92.00^{\mathrm{b}} \\
\pm 10.954\end{array}$ & $\begin{array}{c}100.00^{\mathrm{b}} \pm \\
0.000\end{array}$ \\
\hline $\mathrm{P}_{2}$ & $\begin{array}{c}36.00^{c} \pm \\
8.944\end{array}$ & $\begin{array}{c}56.00^{\mathrm{b}} \pm \\
8.944\end{array}$ & $\begin{array}{c}76.00^{\mathrm{b}} \pm \\
16.733\end{array}$ & $\begin{array}{c}88.00^{c} \pm \\
10.954\end{array}$ & $\begin{array}{c}100.00^{\mathrm{b}} \pm \\
0.000\end{array}$ & $\begin{array}{c}100.00^{b} \pm \\
0.000\end{array}$ \\
\hline $\mathrm{P}_{3}$ & $\begin{array}{c}56.00^{\mathrm{d}} \pm \\
16.733\end{array}$ & $\begin{array}{c}84.00^{\mathrm{c}} \pm \\
8.944\end{array}$ & $\begin{array}{c}96.00^{c} \pm \\
8.944\end{array}$ & $\begin{array}{c}100.00^{c} \pm \\
0.000\end{array}$ & $\begin{array}{c}100.00^{b} \pm \\
0.000\end{array}$ & $\begin{array}{c}100.00^{b} \pm \\
0.000\end{array}$ \\
\hline
\end{tabular}

Different superscripts a.b,c in the same column showed significant differences $(\mathrm{p}<0.05)$.

Based on probit analysis, it showed that the Lethal Concentration of 50 bandotan leaf extract against the B. microplus at 1, 2, 3, 4, 5 and 6 hours respectively was $1.63 \%, 0.85 \%$, $0.54 \%, \quad 0.34 \%, \quad 0.04 \%, \quad 0.04 \%$ and LC_9o bandotan leaf extract at 1,2,3,4,5,6 hours were $5.6 \%, 2.9 \%, 1.8 \%$, respectively. $1.2 \%, 0.16$ and $0.16 \% . \mathrm{LT}_{50}$ values in negative control, positive control and bandotan leaf extract concentrations of $1 \%, 2 \%, 3 \%$ respectively were 10.142 hours, 0.747 hours, 2.184 hours, 1.579 hours and 0.923 hours while the LT9o values were 23.734 hours, 1.749 hours, 5.110 hours, 3.695 hours and 2.159 hours. Based on LC5o, LC90, LT50 and LT9o, it was explained that bandotan leaf extract with a concentration of $3 \%$ showed a faster time to kill ticks by $50 \%$ and $90 \%$ compared to other concentrations and the ability to kill the test ticks was almost the same as the positive control. This shows that bandotan leaf extract with a concentration of $3 \%$ is more effective than the concentration of $1 \%$ and $2 \%$. Aquades is used as a solvent for bandotan leaf extract because it is a neutral and harmless compound, so it is safe to use and does not interfere with the health of the test ticks. The addition of $1 \%$ ethanol to bandotan leaf extract is intended as a suspensator so that bandotan leaf extract can be optimally dissolved in distilled water.

Acaricide is a substance that contains chemical compounds that are used to kill or eradicate mites (Melinda, 2020). According to Melinda (2020), acaricides usually have a dual function, namely as a mite killer and also as an insect killer, because mites are sometimes classified as insects. One of the plants thought to have potential as an acaricide is bandotan leaf. The content of bioactive compounds in bandotan leaves include saponins, flavonoids, polyphenols, and essential oils that can prevent pests from approaching plants (repellents) and inhibit larvae from becoming pupae (Samsudin, 2008). Phytochemical analysis of $A$. conyzoides L. which was carried out by Amadi et al. (2012) showed that the main compounds in bandotan plants, namely alkaloids and flavonoids, accumulate in the leaves. According to Mahendra (2010), bandotan leaves can be developed as a botanical insecticide because they contain active ingredients, namely saponins, tannins, flavonoids, polyphenols and contain essential oils.

Astriani (2010) stated that the chemical content of bandotan is saponins, flavonoids, polyphenols, eugenol and bandotan roots contain essential oils, so bandotan plants can be used as environmentally friendly pesticides. According to Kardinan (2001), bandotan plants have advantages as vegetable pesticides because bandotan plants contain the active compound precocene, besides bandotan leaves also contain alkaloids, flavonoids, coumarins, saponins, polyphenols, and essential oils. Gani (2010) stated that precocene compounds work by interfering with the work of the nervous system in the insect body. Alkaloids are bitter compounds that can cause pests/insects to have no appetite and then die. Alkaloids are also able to inhibit insect growth so that it can cause metamorphosis failure (Dewi, 2016).

\section{Conclusion}

Bandotan leaf extract was effective as an acaricide for $B$. microplus in vitro. The lethal concentration of 50 bandotan leaf extract against the $B$. microplus at $1,2,3,4,5$ and 6 hours respectively was $1.63 \%, 0.85 \%, 0.54 \%$, 
$0.34 \%, \quad 0,04 \%$ and $0.04 \%$, while the LC_9o bandotan leaf extract was $5.6 \%, 2.9 \%, 1.8 \%$, $1.2 \%, 0.16$ and $0.16 \%$, respectively. Lethal Time 50 bandotan leaf extract concentrations of $1 \%$, $2 \%, 3 \%$ respectively were 2.184 hours, 1.579 hours and 0.923 hours while the LT9o values were 5.110 hours, 3.695 hours and 2.159 hours.

\section{References}

Amadi, B., Duru M, dan Agomuo E. 2012. Chemical profilesof leaf, stem, root and flower of Ageratum conyzoides L. Asian Journal of Plant Science and Research. 2 (4): 428-432. 1 (1): 56-67.

Astriani, D. 2010. Pe,amfaatan Gulma Bandotan dan Tembelekan dalam Pengendalian Sitophillus sp Pada Benih Jagung. Jurnal AgriSains

Dewi, A.F. 2016. Pengaruh Variasi Dosis Larutan Daun Bandotan (Ageratum conyzoides L.) Terhadap Mortalitas Larva Nyamuk Aedes Sp. sebagai Sumber Belajar Biologi. Universitas Muhammadiyah Metro. 7 (1): 62-72.

Gani, S. 2010. Uji Efektivitas Tepung Daun Bandotan (Ageratum conyzoides L.) Terhadap Kumbang Beras (Sitophilus oryzae L) (Coleoptera: Curculionidae) di laboratorium. Jurnal Manggaro. 11 (1): 3335 .

Gunandini, D.J. 20o6. Caplak atau Sengkemit dalam Hama Pemukiman Indonesia: Pengenalan, Biologi, dan Pengendalian. Sigit HS, Hadi UK, editor. Bogor (ID). Unit Kajian Pengendalian Hama Pemukiman. 150-157.

Hendrix, C. 2012. Diagnostic Parasitology for Veterinary Technician. Elsevier Mosby. Amerika Serikat.

Jonsson and E.K. Piper. 2007. Integrated control programs for ticks on cattle. University of Queensland. Australia. 135-136.

Kardinan, A. 2001. Pestisida Nabati Ramuan dan Aplikasi. Penebar Swadaya. Jakarta.

Mahendra, Heru. 2010. Perbedaan Toksisitas, Ekstrak Daun Bandotan (Ageratum conyzoides L) Dan Ekstrak Daun Sereh Wangi (Andropogonnardus L) Terhadap Mortalitas Larva Nyamuk Aedes aegypti L. Universitas Jember. Jember.
Manurug, J. 2002. Studi Prevalensi Infeksi Caplak pada Sapi di Kecamatan Ciracap dan Kecamatan Surade kabupaten Sukabumi Jawa Barat dan Cara Peternak Menanggulanginya. Balai Penelitian Veteriner. Bogor

Melinda, N. 2020. Faktor Risiko Keracunan Pestisida Pada Petani Hortikultura Di Desa Rungau Kecamatan Way Tenong Kabupaten Lampung Barat Tahun 2020 [Thesis]. Poltekkes Tanjungkarang. Lampung.

Octavia, Dona, S. Andriani, M.A. Qirom, dan F. Azwar. 2008. Keanekaragaman Jenis Tumbuhan sebagai Pestisida Alami di Savana Bekol Taman Nasional Baluran. Jurnal Penelitian Hutan dan Konservasi alam. 4:355-365.

Rosida, L. A. 2005. Uji Aktivitas Larvasida Ekstrak Kloroform dan Ekstrak Etanol Daun Bandotan (Ageratum conyzoides L.) terhadap Larva Nyamuk Aedes aegypti INSTAR III [Skripsi]. Universitas Muhammadiyah Surakarta.

Samsudin. 2008. Pengendalian Hama dengan Insektisida Botani. Lembaga Pertanian Sehat. www.pertaniansehat.or.id. [3 Juni 2021].

Sukarsih, S., E. Partoutomo., C.H. Satria., Eisemann dan P. Wiladsen. 1999. Pengembangan vaksin myasis: deteksi in vitro respon kekebalan protektif antigen protein peritrophic membrane, pelet dan supernatan larva L1 lalat Chrysomya bezziana pada domba. Jurnal Ilmu Ternak dan Veteriner. 4 (3): 202-208.

Wahyu, A.L. 2017. Uji Aktivitas Ekstrak Daun Sirsak (Annona muricata L.) Pada Caplak (Boophilus microplus) Berdasarkan Waktu Kematian (In Vitro) [Skripsi]. Fakultas Kedokteran Hewan. Universitas Hasanuddin Makasar. 